\title{
REAKTIVITA A TOLERANCE K FRUSTRACI Z POHLEDU PSYCHOLOGIE U ODSOUZENÝCH PACHATELŮ TRESTNÉ ČINNOSTI
}

\author{
KATEŘINA OKROUHLICKÁ
}

\begin{abstract}
Stěžejním tématem práce je reaktivita, respektive způsob chování a projevy reakcí ve chvílích, kdy se jedinec dostane do zátěžové situace nebo mu je zablokováno dosažení určitého cíle. Celá problematika je cílena na odsouzené pachatele trestné činnosti. V českém prostředí tematika reaktivity není př́liš prozkoumaná oblast, přičemž znalost reakcí vězňů ve chvílích, kdy se vyskytnou ve frustrující situaci, by mohla usnadnit následnou práci a snahu o jejich resocializaci. Cílem výzkumu bylo získat kvantitativní údaje o nejfrekventovanějších reakcích u odsouzených pachatelů trestné činnosti ve chvíli, kdy je před ně postavena překážka, která blokuje dosažení cíle či uspokojení jejich potřeb. Výzkumný vzorek činilo 69 odsouzených pachatelů trestné činnosti. Ke zkoumání reaktivity následkem frustrace bylo užito Rosenzweigovy obrázkově frustrační metody. Ze čtyř stanovených hypotéz byla přijata pouze jedna, a to, že pachatelé trestné činnosti v porovnání s introagresivními a imagresivními reakcemi nejvíce uživají reakci extragresivní, tedy reakci orientovanou na vnější okolí. Článek a zjištěné statistické údaje vycházejí z diplomové práce (Okrouhlická, 2015).
\end{abstract}

Klíčová slova: reaktivita, frustrace, zátěžová situace, pachatel, trestná činnost https://doi.org/10.14712/23366486.2017.8

\section{1. Úvod a teoretické vymezení}

Každý z nás je ve vnímání a hodnocení frustrující situace poněkud odlišný. Zatímco pro jednoho může být konkrétní situace zcela neúnosná, druhým může být tatáž situace vnímána naopak jako rutina, která nepředstavuje pro daného jedince žádnou formu zátěže a lehce ji zvládne zpracovat a vyřešit. I přesto, že máme $\mathrm{k}$ dispozici přesné teoretické vymezení pojmu frustrace, je nutné mít i nadále na paměti, že každý jedinec ji může pojímat a chápat poněkud odlišně. Nejenom že problematika frustrace je široké a velmi obsáhlé téma, ale navíc je propojena s dalšími významnými aspekty (obranné mechanismy, copingové strategie aj.). Na klíčové téma reaktivity na frustraci je v této práci nahlíženo z hlediska trestné činnosti u odsouzených pachatelů. Odpověd’ na frustraci může být u každého jiná a může dosahovat jiné intenzity a rozměrů. Pokud má špatné zvládání frustrace vliv na to, že jedinec spáchá trestný čin, nabízí se otázka k zamyšlení, proč je jedna osoba frustrující situaci schopna zvládnout, zatímco jiná se dopustí až trestného činu. Nutno podotknout, že tato problematika ovšem nesouvisí pouze s frustrací samotnou, ale také s naučenými tendencemi reagování, s motivací, s intenzitou a dobou trvání překážky bránící v dosažení cíle a mnoha dalšími aspekty. 


\subsection{Reaktivita v kontextu zátěžových situací}

Braungart-Ricker \& Stifter (1996) hovoří o reaktivitě jako o individuální, somatické, endokrinní či automatické reakci, která odpovídá na podněty bud' z vlastního vnitřního či vnějšího prostředí. Dennis (2006) do reaktivity zase zahrnuje schopnost reagování na nové a neznámé podněty, které tak odrážejí citlivost na potencionální hrozby, strach či nové výzvy. Termín reaktivita může zahrnovat nesčetné množství významů, avšak v této práci je pojato ze sociálně-psychologického hlediska, a to především jako způsob jednání a reagování v situacích, kdy se jedinec dostane do zátěžové situace, která je pro něj více či méně neprŕijemná. $Z$ pohledu forenzní psychologie je možné na reaktivitu nahlížet jako na impulzivní, agresivní, egocentrické či násilné jednání. Výzkumy ukazují (Eisenberg \& Miller, 1987; Lauterbach \& Hosser, 2007), že výše zmíněné projevy chování mohou souviset s nižší mírou empatie. Lidé s deficitem v oblasti empatických schopností obtížně chápou myšlenky a pocity druhých lidí, mají větší tendenci k egocentrickému způsobu chování, hưřre potlačují agresivní a impulzivní tendence a prílišs nedomýšlejí následky a dopady svého chování na druhé osoby. Na druhé straně uvádí, že naopak nadprůměrná schopnost empatie koreluje s prosociálním chováním, tudíž se zdá, že by měla být v podstatě v rozporu s trestným a nezákonným jednáním (Eisenberg \& Miller, 1987; Lauterbach \& Hosser, 2007). Možná právě tato zjištění vedla k tomu, že v některých léčebných programech pro pachatele trestné činnosti využívají nácviků empatických dovedností. Princip je takový, že zúčastněné osoby mají za úkol pokusit se vžívat do oběti - jejího vnímání a pocit’ovaného stavu nepohody následujícího po samotném činu. Uživatelé této metody se domnívají, že vyvolání pocitů obav a úzkosti, kterou pravděpodobně obět' zažívá, může vést ke snížení agresivního a impulsivního jednání u samotných pachatelů (Lauterbach \& Hosser, 2007). Reaktivitu je možné vnímat také v souvislosti s impulzivitou, kdy M. Zuckerman et al. (1993) definují impulzivitu jako touhu po vyhledávání vzrušení, která souvisí se zvýšenou aktivační úrovní (arousal), kdy jedinec vyhledává nějaké nabuzení a vzrušení. V souvislosti již s forenzní psychologií D. W. Shuman a L. H. Gold (2008) mluví o tzv. impulzivní agresivitě, která je doprovázena zvýšenou tendencí ke spontánnímu a unáhlenému jednání. Vzhledem $\mathrm{k}$ tomu, že dávají impulzivitu a agresivitu dohromady, tvrdí, že toto impulzivní chování je v podstatě nutkání k násilí. Nejčastějšími spouštěči je vzniklý stres či frustrace, kdy jedinec v danou chvíli ztrácí kontrolu sám nad sebou a není schopen uvažovat racionálně. Se zajímavou myšlenkou přišel Vasquez et at. (2007). Spolu s ostatními kolegy se zabýval otázkou, v jak silné intenzitě dokáže předchozí frustrující situace ovlivnit naše aktuální vnímání reakce. Může taková frustrace ovlivnit konečné rozhodnutí? Autoři vycházejí z toho, že averzivní událost vyvolává negativní vnímání, a to může způsobit negativní reakci jedince. Do této koncepce zapadá také termín ruminace, což vysvětlujeme jako zaměření se na vlastní myšlenky a pocity. Často se jedná o vtíravé myšlenky. Autoři tvrdí, že zaobírání se těmito myšlenkami může vést k agresivnímu chování, které se u člověka nemusí objevit ihned v návaznosti na tyto myšlenky, ale i po poměrně dlouhém časovém odeznění. Výsledky ukazují, že lidé, kteří př́liš a zdlouhavě přemýšlejí či rozebírají negativní události, mají větší tendence k agresivnímu jednání. Je možné, že pokud jedinec uvažuje a přemítá si danou agresivní situaci, působí to na jeho vnímání a kognici, čímž se více aktivuje i jeho prrípadná tendence k agresi. Sama frustrující situace nemusí tedy vést k vyvolání agresivního jednání, avšak přemýšlení a vracení se k negativním pocitům a myšlenkám určité nepř́znivé situace možná ano (Vasquez et al., 2007). K podobným závěrům došli také 
autoři W. C. Pedersen, C. Gonzales a N. Miller (2000), kteří z výsledků vlastního výzkumu usuzují, že pokud se u jedince objeví určitá náročná situace nebo překážka, která není doprovázena dalšími zatěžujícími okolnostmi a objevuje se poměrně v nepravidelných časových intervalech, nemá pak jedinec takovou tendenci hledat řešení v atypickém či agresivním jednání. Ve chvílích, kdy ale dochází k akumulaci obtížných situací, mohou být tendence $\mathrm{k}$ agresivním činům u člověka zintenzivněny.

$\mathrm{Na}$ reakce z hlediska náročných životních situací je možné nahlížet také procesem adaptace a zvládání (= coping). Zatímco adaptace zahrnuje náročné situace, které jsou v rámci běžných mezí a pro jedince tedy často poměrně snadno zvládnutelné, zvládání je proces, kdy se jedinec vyrovnává již s mnohem obtížnějšími nároky, které jsou co do intenzity a délky trvání hůře zvládnutelné (Křivohlavý, 1994). S. Mohino, T. Kirchner a M. Forns (2004) se v rámci své studie zabývali copingovými strategiemi u vězněných pachatelů. Tvrdí, že v průběhu prvních měsíců uvěznění pachatelé nejčastěji užívají copingové strategie zaměřené na vybití emocí. Autoři navíc doplňují, že prvo-věznění pachatelé v prvních měsících více než recidivisté stále hledají nějakou aktivitu, kterou by se zabavili a vyrovnali se tak lépe se vzniklou situací. Toto období trvá dle autorů okolo čtyř měsíců. Posléze po několika měsících coping strategie zaměřená na vybití emocí ustupuje a do popředí se dostává bud' strategie snahy o pozitivní přerámování, př́padně coping strategie prrijetí-rezignace. U odsouzených pachatelů trestné činnosti se však často očekává, že jejich copingové strategie jsou ve vyšší míře negativního rázu, tedy že častěji užívají méně adaptivní formy zvládání jako je např́íklad emocionální reaktivita, vyhýbání se či popření problému (Archer, 2007; Ireland, 2011). Ovšem jak můžeme vidět z výše popsané studie, ne vždy tomu tak musí skutečně být.

\subsection{Frustrace}

V tomto článku je frustrace chápána vzhledem k zaměření empirické části především z hlediska pojetí S. Rosenzweiga (1945), který frustrujícími označuje situace, kdy jedinec narazí na překážku bránící uspokojení jeho potřeb. Touto překážkou ovšem nemusí být pouze vnější objekt, ale také náš vlastní intrapsychický konflikt. Je radno tedy rozlišovat mezi frustrací pramenící z vlastní psychické nestability a frustrací vyvolanou vnějšími objekty (Berkowitz, 1962). S. Rosenzweig (1938) mluví také o termínu „Frustration-Tolerance“, kterým definuje odlišnost reagování na frustrující situaci, respektive schopnost odolávat frustrujícím situacím po delší období, aniž by byla narušena integrita osobnosti. Tolerance $\mathrm{k}$ frustraci se do značné míry vyvíjí a utváří v průběhu celého vývoje jedince (Rosenzweig, 1938).

Samožrejmě ale existují i jiné teorie a výklady frustrace. Například někteří autoři se domnívají, že projevovaná agrese je následkem právě zmiňované frustrace. S touto teorií přišli jako první autoři z Yaleské univerzity (Dollard et al., 1939 podle Berkowitz, 1962). L. W. Doob a R. R. Sears (1939) zkoumali myšlenku, že každá agresivní reakce na frustraci nemusí být nutně zjevná, avšak můžeme se setkat i s agresí, která je skrytál či dokonce přenesená na náhradní neboli substituční ${ }^{2}$ reakci. Jejich základní hypotézou bylo, že projev agresivního jednání v návaznosti na frustraci závisí jak na intenzitě snahy o dosažení cíle, tak na velikosti trestu, který respondenti očekávali, kdyby se zachovali

I Skrytou agresí autoři myslí agresi, která zůstává v myšlenkách a představách jedince, ale nedochází k jejich projevům navenek.

2 Substituční reakcí může být chování, kdy jedinec nahrazuje vlastní potřebu či agresivní projev za činnost odlišnou. 
agresivně. Výsledky jim přinesly zjištění, že čím nižší byla intenzita snahy o dosažení cíle, tím byl nižší počet otevřených projevů agrese a namísto toho byl vyšší počet substitučního chování. Skrytá agrese se s mírou snažení př́liš neměnila. Otázka očekáváného trestu za agresivní jednání přinesla pouze následující zjištění. Respondenti, kteří se zabývali srovnáním mezi možným trestem a mírou uspokojení z agresivního jednání, vykazovali menší míru agresivních projevů. Na druhé straně se ale ukázalo, že čím důležitější frustrovaná potřeba pro jedince je a čím delší dobu frustrace přetrvává, případně se opakuje, tím je větší tendence k prŕmé agresi bez ohledu na obavy z trestu (Dollard et al., 1939 podle Berkowitz, 1962). Kritici frustrační teorie agrese ovšem tvrdí, že ne veškerá projevená agrese musí být výsledkem frustrace a zároveň ne každá přetrvávající frustrace musí nutně vést k agresivnímu jednání (Berkowitz, 1962). I když není možné zobecȟovat pro každý př́ipad, souvislost mezi frustrací, agresí a emocemi je značná.

A. Amsel a J. Roussel (1952) vnímají frustraci jako motivační proměnou, jejíž síla a intenzita se mění podle délky a doby trvání frustrující situace. Hovoří také o naučené formě frustrace, kterou lze definovat jako podmíněnou reakci na již dříve posílený podnět. R. Lawson a M. H. Marx (1958) říkají, že v průběhu života si jedinec vytváŕí a upevňuje zásobu určitých způsobů chování a reagování na dílčí situace. Ve chvíli, kdy dojde k blokování naučeného způsobu reagování, má jedinec stále ještě řadu jiných naučených způsobů. Frustrace ovšem vzniká a stupňuje se tehdy, čím více osvědčených způsobů reagování je znemožněno.

N. R. F. Maier (1966) zásadně rozlišuje chování podnícené frustrací a chování orientované na cíl. V prvém případě užívá termínu abnormální fixace, $\mathrm{v}$ druhém případě hovoří o chování, jež je poháněno motivací. Za abnormální považuje chování objevující se v situaci, kdy jedinec opakovaně volí stejné způsoby chování a brání se možným změnám či odlišnému způsobu reagování. Jeho reakce jsou rigidní. Toto chování dává také například do spojitosti s jedinci dopouštějícími se kriminálních deliktů. Pracuje s úvahou, že pokud delikventním jedincům k zamezení páchání trestné činnosti nepomáhá trest, tak je možné, že pozorované chování u nepřizpůsobivých jedinců není jejich volbou k takovému chování, avšak chováním, kterému jejich organismus není schopen odolat, případně mu vzdorovat. Na druhé straně ale také mluví o stereotypním a naučeném způsobu chování. Chování delikventních jedinců ovšem může být stereotypní, stejně tak ale vůbec takové být nemusí. Pokud tedy příčinou delikventního jednání není stereotypní způsob reagování na podněty, může jí být naopak impulzivita, kterou právě frustrace může podněcovat. Pokud tedy podle N. R. F. Maiera (1966) nepomáhá trest, je zapotřebí zkoumat proces frustrace, která může být jednou z příčin neadekvátních reakcí. Zatímco u motivovaného chování jedinec svou reakci volí a vybírá nejvhodnější způsob dosažení svých plánů, reakce podmíněná frustrací bývá nutkavá a neovladatelná.

Tzv. Strain theory navíc přidává, že nepatřičné a negativní zacházení může v jedinci generovat negativní emoce a pocit frustrace, jež může stupňovat pocit’ovanou agresi a vést k touze po pomstě. Název „Strain theory“ je překládán jako teorie napětí a snaží se delikventní chování vysvětlovat skrze frustraci a skrze snahu o únik od negativního zacházení (Agnew, 1985; Blatníková \& Netík, 2008). Strain theory hovoří navíc o tom, že se jedinec může dostat do tíživé a bolestné situace, ze které se snaží uniknout. Je na „cestě úniku“, ale tento únik je mu nakonec zmařen a blokován a již nemá cesty zpět. V tuto chvíli může tedy právě dojít k navyšování agrese a pod tíhou napětí též k spáchání trestního činu (Agnew, 1985). Zastánci frustrační teorie agrese a strain theory jsou 
názoru, že právě negativní životní zkušenosti mají negativní dopad na chování lidí, které může vyústit právě v kriminální chování a páchání trestné činnosti (Agnew, 1985; Berkowitz, 1962). A.S.Giannell (1966) ř́ká, že také zločin z vášně může být řazen pod trestné činy páchané důsledkem dlouhodobé frustrace. Je zastáncem toho názoru, že se člověk v danou chvíli dostává do tak extrémního emočního stavu, že zcela opomíjí vlastní vnitřní zábrany. J. L. Huck et al. (2012) propojili strain theory spolu s copingovými strategiemi. Podle jejich teorie převládání negativních emocí silně koreluje s využíváním negativních copingových strategií, které mohou vyústit až v deviantní a kriminální chování. Naopak jedinci, u kterých převládají pozitivní emoce, jsou častěji ve větší míře schopni užít patřičné copingové strategie.

\subsection{Osobnost pachatele trestného činu z pohledu reaktivity na frustrující situaci}

Trestným činem se rozumí jakýkoliv protiprávní čin, který je v trestním zákoníku vymezen za trestný (Trestní zákoník, 2015). Z pojetí psychologického lze hovořit o trestném činu jako o ,,výsledku specifické lidské činnosti“ (Gillernová \& Boukalová, 2006, s. 78). Při užití termínu osobnost pachatele předem předpokládáme, že máme k dispozici určitý souhrn vlastností a rysů, které jsou pro delikventy běžné a které zodpovídají za jejich kriminální chování (Netík et al., 1997). Jeden striktně vymezený přehled osobnostních typologií pachatele k dispozici ovšem nemáme. Existuje však řada autorů, kteří se danou problematikou zabývají a s jejichž vymezením charakteristik pachatele se můžeme setkat. L. Berkowitz (1962) rozlišuje nejprve dva typy pachatelů, u kterých zkoumá příčinu či podnět, jež vedl ke spáchání určitého přestupku či porušení sociálních norem individualistický typ delikventa a socializovaný typ delikventa. Autor podotýká, že individualističtí delikventi konají trestné činy pod návalem silných emocí, jež nejsou sto plně kontrolovat. Naopak u socializovaných delikventů se domnívá, že jejich trestné činy jsou nedílnou součástí jimi naučených modelů chování v průběhu dětství.

K. Netík (1997) na základě kriminálního jednání rozlišuje následující typy osobností. Socializovaný typ. Socializovaný delikvent nevykazuje známky existence nějaké poruchy a je nejméně ze všech zasažen asociálním chováním. Pokud je dopaden, zřídka kdy klade odpor. Vyznačuje se spíše kooperací. Neurotický typ. Poháněn vlastním intrapsychickým konfliktem, který si ve většině případů neuvědomuje. Je charakteristický úzkostí a výskytem obranných mechanismů, které se v zátěžové situaci ještě zvýrazní. Defektně socializovaný typ. Označován také jako psychopatický typ nebo typ s asociální poruchou osobnosti. Není schopen regulovat vlastní emoce a chování, postrádá inhibiční mechanismy zabraňující nežádoucímu chování. V jeho chování se často vyskytuje nadměrné lhaní, oploštělá emocionalita a agresivita. Jeho vidění světa je v podstatě dvojdimenzionální - jedinci silní vs. slabí. Mentálně nedostačivý typ. Jedinec se sníženou inteligencí. Dopouští se spíše násilných činů, případně činů se sexuální atakou často na inadekvátních objektech. Jeho čin není nikterak důkladně promyšlený, naopak bychom mohli říci spíše až primitivní. V případě, že způsob trestné činnosti byl důmyslnější, zvažujeme přítomnost spolupachatele. Deviantně socializovaný typ. Jedinec nemá obtíže v osvojování si norem, ovšem jedná se o normy kulturně podmíněné prostředím, kde jedinec vyrůstá. Akceptuje delikventní normy své subkultury, které jsou ale v rozporu s normami společnosti. Typ s masivní psychickou poruchou. Označován zároveň jako typ psychotický, který za svůj čin často nebývá trestně odpovědný. Motivace je často nejasná až bizarní. Delikty jsou nejčastěji násilné povahy, a to převážně se zaměřením na své blízké okolí. 
Známkou duševní poruchy není sama agrese, která je často velmi brutální, avšak doprovázené potěšení a míra vzrušení.

Vztahem mezi zločinností a osobnostními vlastnostmi se zabývali také autoři S. E. Jones, J. D. Miller a D. R. Lynam (2011). Podle názoru těchto autorů se u pachatelů trestné činnosti setkáváme nejčastěji s osobností vyznačující se antisociálním způsobem chování. Osobnost jedince je ovšem relativně stálá, na základě čehož se autoři domnívají, že i sklon $\mathrm{k}$ antisociálnímu jednání je $\mathrm{v}$ osobnosti jedince stabilní. Na druhé straně se ale i některé osobnostní charakteristiky v průběhu vývoje mohou měnit. Nejvíce se v souvislosti s tím zmiňuje svědomitost a emoční stabilita. Otázkou tedy zůstává, proč někteří jedinci na stresující a frustrující situace reagují vnějšími projevy (dávají najevo svůj hněv, zklamání) a jiní se naopak uzavírají raději do sebe (úzkost, výčitky aj.).

Svou roli v problematice páchání trestné činnosti má jistě také možná psychopatologie, což je ovšem poměrně obsáhlé téma, proto jej v této práci do detailů rozvádět nebudeme. Pro pochopení osobnosti páchající trestnou činnost je jistě nápomocné také určení motivace vedoucí k takové činnosti. Např́íklad podle J. E. Douglase et al. (1986) se jedná o nelehký úkol, a to vzhledem $\mathrm{k}$ potřebě ponořit se do myšlenek a možného způsobu chování pachatele. Říká, že o něco snadněji se určuje motivace u takových zločinů, které vykazovaly známky organizovanosti a měly svůj plán. Na druhé straně tvrdí, že u činů, které byly nápadné svou výraznou logickou nesoudružností, je možné uvažovat o činech páchaných lidmi s duševní nemocí. V každém případě jeho základní postup při určování motivace spočíval ve vymezení a studování behaviorálních aspektů pachatele - vymezení typologie pachatele, způsob spáchání trestného činu, místo, čas, orientace a dobrá znalost okolí pachatelem a v neposlední řadě samotné umístění oběti.

L. B. Schlesinger (2004) popsal celkem pět motivačních podnětů, které vedou k trestné činnosti. Environmentálně stimulované trestné činy: Jedinec páchající trestný čin stimulovaný prostředím nemusí být ve většině př́ípadů ani psychotický, ani jeho osobnost nemusí být nikterak narušena. Často se může jednat o činy páchané ve skupině, kde pod tenzí davu jedinci ztrácejí pocit vlastní odpovědnosti. Sociálně stimulované trestné činy: Činy, které jsou vyvolané stresující událostí, kdy daný jedinec často netrpí žádnou osobnostní poruchou. Jedná se často o spontánní akt vyplývající z vnějšího či vnitřního stresového podnětu. Impulzivita pachatele: Tito jedinci nedokáží vnímat svůj život v celé jeho perspektivě, nýbrž se zaměřjí na aktuální momenty. Osobnostně jsou spíše pasivnější, ovšem s neadekvátní tendencí reagovat přehnaným způsobem na vyvolané podmínky životního prostředí. Jejich pocity jsou často provázány hněvem, pocity nepřátelství a nespecifikovatelnou potřebou po pomstě. Pokud se dostanou do tenze, okamžitě ji potřebují vybít, nedokáží usměrňovat svoje emoce a jejich činy jsou nepředvídatelné. Trestné činy jsou často nestrukturované bez známky jakéhokoliv předchozího plánování. Katathymně stimulované trestné činy: $V$ katathymní trestné činnosti jsou emoce pachatele mnohem hlubší, často pramenící z nedostatku či neschopnosti sexuálního kontaktu, který končí až násilným výbuchem, který není plánovaný. Kompulzivní trestné činy: Spáchat trestný čin je pro jedince tohoto typu velice nutkavá a silná potřeba, která má podobu rituálu a která má tendenci se opakovat. Není náhodou, že právě kompulzivní trestné činy spatřujeme nejčastěji u sériových vrahů. Primární motivací je sexuální akt, který je na rozdíl od katathymní trestné činnosti spojen s potřebnou dávkou agrese, a právě ta je zdrojem vzrušení. 


\section{Cíl výzkumu}

Hlavním cílem práce bylo posouzení způsobu reagování pachatelů trestné činnosti v situacích, které jsou více či méně vnímány jako frustrující. Dalším cílem bylo také prozkoumání trestných činů a jejich souvislosti právě se zmiňovanými způsoby jednání v reakci na frustrující události. Vzhledem k použité Rosenzweigově obrázkové frustrační metodě byly způsoby reagování zacíleny především na chování extragresivní, introagresivní a imagresivní. Jednou ze zvolených metod byl také polostrukturovaný rozhovor, jehož využití bylo zacíleno na porovnání a dokreslení výsledků získaných z PFT metody. Účelem zmíněné metody bylo také zmapovat okolnosti, pocházející z osobní historie či zkušenosti, a že znalost historie jedince může poskytnout komplexnější pohled na zkoumanou osobu.

\section{Hypotézy}

Hypotéza 1: Extragresivní reakce se u pachatelů trestné činnosti objevují častěji než reakce introagresivní a imagresivní.

Při zkoumání této hypotézy je extragresivní reakce pojímána ve smyslu sklonu jedince k obviňování, výčitkám a nepřátelství orientovanému vůči druhým osobám (E), zdůrazňování př́ítomnosti frustrující situace ( $E^{\prime}$ ) či očekávání, že s řešením frustrující situace přijde někdo jiný (e).

Hypotéza 2: Extragresivní reakce se u pachatelů trestné činnosti objevují častěji než u obecné populace.

Obecnou populací je zde míněno porovnání pachatelů trestné činnosti s dostupnými normami.

Hypotéza 3: Pachatelé násilných trestných činů ve větší míře než pachatelé trestních činů bez použití násilí zdůrazňují převládání překážky (= obstacle-dominance, O-D).

Mezi trestné činy s použitím násilí jsou v této práci řazeny - vražda, násilné činy a činy mravnostní. Mezi trestné činy bez použití násilí - krádeže vloupáním a krádeže prosté, majetkové činy, ostatní kriminální činy, zbývající kriminalita a hospodářské činy. Reakcí obstacle-dominance je myšleno takové chování, kdy jedinec zakotvuje ve fázi stížností na tíživost nastalé situace a nesnaží se ani o obranu vlastního chování (E-D), ani neusiluje o překonání překážky a nalezení řešení (N-P).

Hypotéza 4: Pachatelé násilných trestných činů častěji než pachatelé trestních činů bez použití násilí zdůrazňují extrapeditivní ( $\left.E^{\prime}\right)$ převládání př̌kážky.

Extrapeditivní reakce $\left(E^{\prime}\right)$ zdůrazňuje a upozorňuje na prŕtomnost frustrující překážky.

\section{Výzkumný soubor}

Výzkumný vzorek sestával pouze z mužů $(\mathrm{N}=69)$ české státní př́islušnosti. Věk respondentů se $\mathrm{v}$ době sběru dat pohyboval $\mathrm{v}$ rozmezí od 19 do 58 let, přičemž průměrný věk činil 34. Směrodatná odchylka činila 8,71 , medián 31 let. Zmíněný věk pachatelů se vztahuje $\mathrm{k}$ aktuálnímu věku $\mathrm{v}$ době sběru dat, nikoliv ke věku $\mathrm{v}$ době spáchaného trestného činu. 
Tabulka 1 Rozložení respondentů s ohledem na věznici, ve které jsou umistěny

\begin{tabular}{|l|c|c|}
\hline \multirow{2}{*}{ VĚZNICE } & \multicolumn{2}{|c|}{ CELKOVÝ POČET RESPONDENTU゚ } \\
\cline { 2 - 3 } & Absolutní počet & Podíl souboru \\
\hline Plzen̆ & 41 & $59,4 \%$ \\
\hline Praha - Pankrác & 20 & $29,0 \%$ \\
\hline Hradec Králové & 8 & $11,6 \%$ \\
\hline Celkem & 69 & $100 \%$ \\
\hline
\end{tabular}

Z hlediska nejvyššího dosaženého vzdělání nejpočetnější skupinu tvořili respondenti se základním vzděláním (47,8 \%). Následovali respondenti s výučním listem $(34,8$ \%) a s maturitou (15,9\%). Vysokoškolské vzdělání mělo pouze 1,5\% respondentů.

Výzkumný soubor byl rozčleněn také na základě spáchané trestné činnosti, a to podle MV ČR (2015) celkem do osmi kategorií - vraždy, násilné činy, mravnostní činy, krádeže vloupáním a krádeže prosté, majetkové činy, ostatní kriminální činy, zbývající kriminalita a hospodářské činy. MV ČR (2015) uvádí veškeré trestné činy, které do kategorie spadají. Zde uvádím pouze ty, které se ve výzkumném souboru objevily:

1. Vražda

2. Násilné trestné činy: únos, loupež, úmyslné ublížení na zdraví, vydírání, omezování svobody

3. Mravnostní trestné činy: znásilnění, pohlavní zneužívání, soulož mezi př́ibuznými

4. Krádeže vloupáním: vloupání do domu, obchodu a jiných objektů, a Krádeže prosté: krádeže různých součástek, krádež na osobách

5. Majetkové trestné činy: podvod, zpronevěra, neoprávněné užívání cizích věcí

6. Ostatní kriminální trestné činy: výtržnictví, sprejerství, šíření toxikománie, zneužívání pravomoci úřední osoby, maření úkolů úřední osoby z nedbalosti, maření výkonu úředního rozhodnutí, nedovolené ozbrojování

7. Zbývající kriminalita: zanedbání povinné výživy

8. Hospodářské trestné činy: úvěrový podvod, pojistný podvod, úplatkářství, trestné činy proti měně

V prŕípadě, že pachatel spáchal větší množství činů a jejich dělení nespadalo do jedné kategorie, byla vybrána kategorie závažnější, na základě které měl vyměřen nejdelší délku trestu.

\section{Zvolené metody}

Rosenzweigova obrázkově frustrační metoda (dále jen PFT) je technikou, která se zaměřuje na chování lidí v situacích, které se mohou v běžném životě snadno přihodit a které na nás mohou působit i jako zátěž či stres (Rosenzweig, 1945). J. Šípek (2000) metodu PFT řadí pod apercepčně vizuální projektivní techniky, jejichž základním principem je dotváření určitých skutečností, situací, př́běhů, obrázků aj. K tomuto účelu zkoumaný jedinec používá především, a hlavně vlastní fantazii, díky které se na rozdíl od osobnostních dotazníků dozvídáme více o jeho dynamice chování a osobnostní výjimečnosti. Projekce je zde vnímána především v tom smyslu, že se daný jedinec vžívá do postavy na obrázcích, odpovídá namísto nakreslené osoby a skrze ni promítá své vlastní postoje a způsob chování (Rosenzweig, 1976). 
PFT obsahuje celkem 24 obrázků, které mají reprezentovat každodenní situace, které se nám mohou běžně přihodit, avšak vyhodnocujeme je (at' již v menší či větší míře) jako situace frustrační či zatěžující. Frustraci S. Rosenzweig vnímá jako překážku, která brání v dosažení, naplnění a uspokojení potřeb. Přítomnost stresu či frustrace signalizuje zvýšené napětí, které může mít za následek vyčerpání a může vést k projevu agrese. $\mathrm{Na}$ každém obrázku jsou dvě, případně i více osob, přičemž osoba vlevo vždy danému jedinci (respondentovi) sděluje jakousi informaci. Na respondentovi následně je, aby do prázdného políčka vpravo vepsal svoji reakci, a to pokud možno tu, která jej napadne jako první a o které si myslí, že by u něj v reálné situaci skutečně nastala (Rosenzweig, 1976).

Situace, které jsou na obrázcích znázorněny, rozdělil S. Rosenzweig na dva hlavní typy, a sice ego-blocking a superego-blocking. Obě zmíněné situace svým způsobem útočí na osobu jedince, ovšem s tím rozdílem, že zatímco ego-blocking situace staví před jedince překážku, která mu maří uspokojení a neumožňuje dosažení žádoucího výsledku, superego-blocking situace jsou již více zaměřené na přímý útok a obviňování zkoumané osoby (Rosenzweig, 1945). Nás následně zajímá, jakým způsobem lidé na tyto situace reagují, jak jednají a jak je jejich reakce, př́ípadně agrese orientována. S. Rosenzweig (1976) rozlišuje mezi typem agrese a směrem agrese. Pro účely práce ovšem bylo vhodnější toto členění definovat jako rozlišení dle typů a směru reakcí.

Rozlišení dle typů reakce (Rosenzweig, 1976): 1. obstacle-dominance (O-D) - jedinec ve své reakci zvýrazňuje překážku, která mu je stavěna do cesty; 2. ego-defense (E-D) snaha jedince bránit a obhajovat sebe sama, 3. need-persistence (N-P) - zaměření na cíl bez ohledu na překážky, snaha o řešení.

Rozlišení dle směru agrese (Rosenzweig, 1976): 1. extraggression (E-A) - agrese je zaměřena na okolí; 2. intraggression (I-A) - agrese je zaměřena na sebe sama, na vlastní osobu; 3. imaggression (M-A) - přehlížení či přenesení se přes frustraci.

Zjednodušeně řečeno E-A agrese směřuje ven, I-A je obrácena a zaměřena na vlastní osobu, M-A agrese jakoby byla potlačená a vypnutá.

V celkovém souhrnu hovoří S. Rosenzweig (1976) o šesti tzv. kategoriích (složeno ze tří typů agrese a ze tří směrů agrese), které vzájemnou kombinací vytvářejí devět možných faktorů hodnocení reakce respondenta. Definice faktorů hodnocení reakce respondenta:

1. Extrapeditivní $\left(E^{\prime}\right)$ - zdůraznění přítomné frustrující př̌ekážky

2. Extrapunitivní (E) - výčitky, neprátelství aj. jsou obráceny proti určité osobě či subjektu v okolí

3. Extrapersistivní (e) - řešení frustrující překážky očekává od někoho jiného

4. Intropeditivní $\left(I^{\prime}\right)$ - danou situaci jedinec nevnímá jako frustrující, ba naopak někdy dokonce jako prospěšnou

5. Intropunitivní (I) - obviňování a kritiku jedinec směřuje na sebe sama; jedinec připouští svoji chybu a neodvolává se na nevyhnutelné okolnosti

6. Intropersistivní (i) - snaha o řešení nastalé situace $\mathrm{z}$ důvodu vlastních pocitů viny

7. Impeditivní $\left(M^{\prime}\right)$ - existence frustrující př̌ekážky je minimalizována, dokonce téměř až popřena

8. Impunitivní (M) - situace je vnímána jako nevyhnutelná, avšak nedochází k obviňování sebe sama ani frustrující osoby

9. Impersistivní (m) - vyjádření naděje, že řešení problému přinese čas; charakteristická je zde trpělivost a konformita. 
K těmto výše zmíněným faktorům jsou navíc přidány ještě další dva (Diamant \& Srnec, 1958):

1. $\underline{E}$ - je variantou $\mathrm{k} E, \mathrm{kdy}$ jedinec agresivně popírá, že by byl odpovědný za nastalou situaci

2. I - je variantou k I, kdy jedinec svoji vinu uznává, ale odmítá jakoukoli podstatnou chybu na své straně a zdůrazňuje nevyhnutelné okolnosti.

Poslední použitou metodou, ovšem pouze u dvou vězněných osob, byl polostrukturovaný rozhovor. $\mathrm{V}$ rámci polostrukturovaného rozhovoru, který u obou pachatelů trval okolo čtyřiceti pěti minut, byla pozornost orientována na tyto čtyři klíčové oblasti:

1. Reakce v zátěžových situacích

2. Popis reakcí druhými lidmi

3. Rodina a rodinná historie

4. Popis trestného činu.

Pohovor byl zahájen dotazováním na první oblast - zjišt’ování reakcí v zátěžových situacích. Užívány byly nejprve obecné otázky. Důvodem bylo především prolomení prvotních př́ípadných ostychů. Druhá oblast v konečném důsledku nebyla pro účely práce př́liš užitečná. U jednoho respondenta byla zcela vynechána, poněvadž respondent uváděl mnohem hodnotnější informace svého života, než by obnášely informace z druhé oblasti. Obdobný prŕípad nastal i u druhého respondenta, kde byla zmíněná oblast prozkoumána pouze okrajově. Hodnotnými zdroji informací byly u obou pachatelů především oblasti tři a čtyři, respektive zmapování jejich dětství, rodinných vztahů a motivů, které je ke spáchání trestného činu vedly. Získané informace od obou pachatelů jsou detailněji rozepsány v diplomové práci (Okrouhlická, 2015) v podobě zmiňovaných oblastí, nikoliv v podobě přesného zápisu slovo od slova. Životní souvislosti pachatelů jsou na závěr propojeny s výsledky z PFT metody spolu s připojenou krátkou úvahou, jak se životní příběhy spolu se statistickými výsledky vzájemně doplňují.

\section{Výsledky}

Pro kvantitativní zpracování dat byly použity testy - Friedmannův test, Wilcoxonovům párový test, jedno výběrový t-test a Mann - Whitneyův test. U všech testů byla zvolena hladina významnosti $\alpha=0,05(5 \%)$.

Hypotéza 1. říkající, že extragresivní reakce se u pachatelů trestné činnosti objevují více než reakce introagresivní a imagresivní, byla na základě pozorovaných údajů přijata. Výsledky těchto srovnání ukazují tabulky 2 a 3.

Tabulka 2 Četnost výskytu jednotlivých reakcí

\begin{tabular}{|l|c|c|c|c|c|}
\hline \multicolumn{7}{|c|}{ Popisná statistika } \\
\hline & $\mathrm{N}$ & Mean & Std. Deviation & Minimum & Maximum \\
\hline Extragresivní & 69 & 9,1232 & 3,13121 & 2,00 & 18,00 \\
\hline Introagresivní & 69 & 7,1522 & 2,04059 & 1,00 & 12,00 \\
\hline Imagresivní & 69 & 7,5217 & 2,36928 & 2,50 & 12,00 \\
\hline
\end{tabular}


Tabulka 3 Testová statistika s využitím Friedmannova a Wilcoxonova párového testu

\begin{tabular}{|l|c|c|c|c|}
\hline Friedmannův test & \multicolumn{3}{|c|}{ Wilcoxonův párový test } \\
\hline $\mathrm{N}$ & 69 & & $\begin{array}{c}\text { introagresivní - extra- } \\
\text { gresivní }\end{array}$ & $\begin{array}{c}\text { imagresivní- } \\
\text { extragresivní }\end{array}$ \\
\hline Chi-Square & 9,906 & $\mathrm{Z}$ & $-3,280 \mathrm{a}$ & $-2,312 \mathrm{a}$ \\
\hline Df & 2 & Asymp. Sig. (2-tailed) &, 001 &, 021 \\
\hline Asymp. Sig. &, 007 & & & \\
\hline
\end{tabular}

Hypotéza 2. říkající, že extragresivní reakce se u pachatelů trestné činnosti objevují více než u obecné populace, byla zamítnuta. Výsledky zkoumání ukázaly, že výskyt extragresivních reakcí u pachatelů trestné činnosti a u obecné populace není stejný. Extragresivní reakce se u pachatelů trestné činnosti $(\mu=38,29)$ objevují méně než extragresivní reakce u obecné populace $(\mu=48,74)$.

Hypotéza 3. říkající, že pachatelé násilných trestných činů více než pachatelé trestných činů bez použití násilí zdůrazňují převládání překážky (= obstacle-dominance, O-D), byla také zamítnuta. Zdůrazňování převládání překážky se vyskytuje více u pachatelů bez použití násilí $(\mu=36,08)$ oproti pachatelům s použitím násilí $(\mu=32,98)$.

Rovněž hypotéza 4., že pachatelé násilných trestných činů více než pachatelé trestných činů bez použití násilí zdůrazňují extrapeditivní ( $\mathrm{E}^{\prime}$ ) převládání překážky, byla zamítnuta. Výsledky ukázaly, že extrapeditivní reakce se vyskytují více u pachatelů bez použití násilí $(\mu=37,59)$ oproti pachatelům s použitím násilí $(\mu=30,15)$.

Součástí empirické části byly také dva polostrukturované rozhovory s odsouzenými vězni. Př́běh vězňů a obsah zmíněných rozhovorů je možné si přečíst v diplomové práci (Okrouhlická, 2015).

\section{Diskuse}

\subsection{Výstupy testování}

Testování první hypotézy ukázalo, že extragresivní reakce se v porovnání s reakcemi introagresivními a imagresivními u pachatelů trestné činnosti objevují nejfrekventovaněji. Ovšem i přesto, že se extragresivní reakce u pachatelů trestné činnosti objevují nejvíce, testování druhé hypotézy ukázalo, že v menším měřítku než u obecné populace. $Z$ výsledků vyplývá, že zvolený výzkumný vzorek směřuje svou agresi na okolí méně než obecná populace. Nezanedbatelnou úlohu zde představuje rovněž aspekt, do jaké míry respondenti odpovídali a zaznamenávali odpovědi podle jejich skutečného jednání, pokud by se do obdobné situace dostali. Svou roli může hrát rovněž snaha o zkreslení výsledků a odpovědí s úmyslem udělat dobrý dojem, a to za účelem eliminace negativního vlivu na samotný pobyt ve vězení. M. McMurran a G. Christopher (2009) tvrdí, že pachatelé trestné činnosti pobývající ve vězeňském prostředí mívají často strach a cítí se nejistě ve chvílích, kdy mají řešit nějaký vzniklý problém a raději volí ústupné kroky, které by $v$ běžném životě jinak pravděpodobně nepodnikali. Důvodem takovéhoto jednání je dle posledně uvedených autorů ta skutečnost, že si nechtějí zbytečně stěžovat a tím např. dávat podněty $\mathrm{k}$ prípadnému prodloužení pobytu ve vězení. Obdobné informace zazněly 
také v rozhovoru. Oba vězni zmiňovali, že i přesto, že by se někdy se spoluvězni nejraději pohádali a vyř́kali si vzniklé konflikty, raději se stáhnou sami do sebe a snaží se problém přejít a neřešit. Každý konflikt s sebou nese následky a oba uváděli, že si nechtějí zbytečně komplikovat pobyt ve vězení či dokonce prodloužit výkon trestu. Přece jenom vězení vytváŕí jisté mantinely - omezený počet osob, konkrétní lidi na cele, s nimiž musí vydržet a alternativa odchodu není možná. Předem se proto raději snaží vyhnout kázeňským obtížím, na rozdíl od fungování na svobodě, kdy projevená agrese nemusí mít takové následky jako př́ípadné prodloužení trestu vězně.

Třetí i čtvrtá výzkumná hypotéza byla zaměřena na zkoumání zdůrazňování převládající překážky u pachatelů trestné činnosti bez použití násilí a pachatelů trestné činnosti s použitím násilí. Zatímco třetí hypotéza zkoumala více obecné zdůrazňování převládání překážky (obstacle-dominance), čtvrtá hypotéza se zajímala o konkrétní extrapeditivní reakci. Vzhledem $\mathrm{k}$ tomu, že ani jedna $\mathrm{z}$ hypotéz nebyla príijata, bylo by zajímavé více prozkoumat psychickou odolnost těchto pachatelů v souvislosti se spáchaným deliktem, př́padně charakteristiky samotného trestného činu.

\subsection{Použité metody}

Ke zjišt'ování způsobů reagování u pachatelů trestné činnosti na frustrující situaci byla použita Rosenzweigova obrázková frustrační metoda, která je sice př́nosnou metodou pro zjišt'ování reaktivity na frustraci, ovšem je otázkou, do jaké míry je vhodnou metodou na výzkumný vzorek skládající se z pachatelů trestné činnosti. Vhodnost užití metody by se ovšem dala rozlišit u pachatelů, kteří jsou již určitou dobu ve výkonu trestu a pachatelů, kteří jsou teprve vyšetřovaní. Pachatelé, kteř́ jsou již nějakou dobu ve vězení, mohou mít určité naučené reakce a snaží se chování modifikovat tak, aby si svou situaci nekomplikovali kázeňskými přestupky. Zároveň u nich může panovat strach, že kdyby odpověděli podle vlastního uvážení, mohlo by to s sebou nést jisté následky a ovlivnit tak jejich výkon trestu. Pachatelé, u kterých teprve probíhá vyšetřování, své reakce zatím nemají přizpůsobené vězeňskému životu, a proto mohou být více odpovídající jejich skutečnému způsobu reagování. J. R. Vane (1954) použila metodu PFT pro srovnání delikventních a nedelikventních dívek stejného věku a obdobné inteligence, které pocházely z podobného socioekonomického prostředí. Ukázalo se, že delikventní dívky vyjadřovaly menší než průměrnou tendenci k agresi směřovanou na okolí, nesoustředily se tolik na frustrující objekt, ale naopak se nastalé problémy snažily řešit. Překvapivé nebylo zjišsění, že se delikventní dívky lišily od norem dívek nedelikventních, ale fakt, že delikventní dívky vykazovaly mnohem nižší míru agresivních projevů než naopak dívky nedelikventní. Autorka je toho názoru, že touha po vytvoření dobrého dojmu mohla být jednou z klíčových proměnných, přičemž schopnost udělat dojem není $\mathrm{v}$ tomto př́padě nikterak modifikována mírou inteligence. Na základě takové studie by bylo možné říci, že metoda PFT není pro zkoumání reakcí delikventních pachatelů vhodná, protože ti s ní dokáží poměrně snadno manipulovat (Vane, 1954). Na druhé straně jiná studie (Hornsveld et al., 2007) zaměřená na kriminalistickou minulost u psychiatrických pacientů ukazuje, že neurotismus, agresivní a nepřátelské projevy je možné zkoumat i s použitím zkrácené verze PFT metody (namísto použití 24 obrázků vykreslujících danou frustrační situaci využívá pouhých 12 obrázků). Výsledky studie ukázaly, že i tato zkrácená verze pozitivně korelovala se škálou neurotismu, s testy změřenými na agresivní chování a s projevy nepřátelských myšlenek. Naopak negativní korelace byla zaznamenána mezi hostilitou a extraverzí, otevřeností, prŕivětivostí a svědomitostí. 


\subsection{Limity, přínosy, náměty pro další výzkum}

Jedním z klíčových nedostatků výzkumu je nízký počet respondentů. Vzhledem $\mathrm{k}$ tomu, že se jedná o vězněné osoby, nebylo získat přístup do věznice př́iliš snadným úkolem. Pro přesnost výsledků a vyšší homogenitu by nicméně bylo zajisté vhodné, pokud by celkový počet zúčastněných osob byl mnohem vy̌šší a zároveň pokud by byly početnějš́ také podskupiny jednotlivých typů trestných činů. Z hlediska výzkumného vzorku je dalším nedostatkem rozložení trestné činnosti. Předem nebylo určeno, jaké specifické trestné činy mají do výzkumného vzorku spadat, proto byli vybráni ti respondenti, jež měli zájem se na výzkumném šetření podílet. $V$ ideálním případě by bylo v budoucnu vhodné stanovit si předem, jaké trestné činy jsou požadovanou zkoumanou proměnnou a získat tak homogenní rozdělení počtu respondentů.

I přesto, že se jednalo o respondenty, kteří se převážně do výzkumného šetření přihlásili dobrovolně, byli mezi zúčastněnými i ti jedinci, kterým byla př́itomnost na sběru dat doporučena $\mathrm{z}$ důvodu nabytí bodů za aktivitu ve věznici. Tito respondenti se $\mathrm{v}$ rámci inquiry několikrát přiznali, že svou účast jako zcela dobrovolnou nevnímali. Dobrovolná či nedobrovolná účast na výzkumu také do jisté míry mohla zkreslit samotné výsledky, protože př́istup $\mathrm{k}$ testu jednotlivých věznu byl individuální.

V rámci výzkumného vzorku je nutné také zmínit výběr věznic. Zajisté by bylo př́nosné využít co nejširší škálu typů věznic z různých částí České republiky. Tento požadavek se bohužel splnit nepodařilo. $Z$ pěti oslovených věznic souhlasily se spoluprací pouze tři z nich, což může mít na zjištěné výsledky také určitý vliv.

Rozdělení trestné činnosti probíhalo podle statistického přehledu Ministerstva vnitra ČR (2015). Problematické ovšem bylo, pokud jeden respondent spáchal více trestných činů. Ve valné většině se jednalo o trestné činy v rámci jedné kategorie, ovšem byly i delikty, které pod jednu stejnou kategorii nespadaly. $V$ takovém př́ípadě byl respondent zařazen do kategorie závažnějšího trestného činu, který byl určen dle délky vyměřeného trestu. Dělení na více či méně závažné trestné činy je problematické a pro každého jedince může závažnost znamenat něco jiného, proto hlavním určujícím kritériem bylo, zda v rámci svého deliktu jedinec spáchal trestný čin s použitím násilí či bez použití násilí. Toto dělení má ovšem také své limity, nebot' záleží též na miŕ̌e a charakteru použitého násilí, kdy i v rámci jedné kategorie může být míra a charakter užitého násilí odlišný.

Dalším limitujícím faktorem byl také samotný sběr dat. Vyplňování PFT protokolu probíhalo hromadně, kdy všichni vězni byli shromážděni v jedné společné místnosti, kde měl každý na stole připravený jeden protokol a propisovací tužku. Tento způsob sběru dat byl zvolen především s ohledem na množství členů personálu $\mathrm{v}$ jednotlivých věznicích, kteří mohli být u vězňů prrítomni po celou dobu vyšetření. Vzniklé obtíže s hromadným zadáváním nepatrně zmírnilo následné inquiry, které již probíhalo individuálně a sloužilo k ožrejmění a zpřesnění odpovědí. Na druhou stranu je nezbytné zmínit, že inquiry se vždy zúčastnil také jeden ze zaměstnanců věznice (psycholog či speciální pedagog), což mohlo mít na druhou stranu na respondenta negativní dopad z hlediska anonymity výsledků testu. U dvou vězňů proběhl následně po inquiry navíc přibližně čtyřiceti pětiminutový polostrukturovaný rozhovor. Rozhovor byl velice přínosným a dokreslujícím zdrojem informací. Vzhledem k tomu, že oba vězni byli velmi ochotní a otevření vzájemné komunikaci, byla škoda, že na některé informace již nezbyl větší časový prostor. Původně bylo záměrem učinit takových rozhovorů více, ovšem kapacitní možnosti personálu jednotlivých věznic další šetření neumožňovaly. Zároveň by bylo jistě př́ínosné, pokud 
by se objektivnost zjištěných informací dala ověřit nahlédnutím do dokumentace. Takový postup bohužel možný ovšem nebyl. Vhodné by minimálně také bylo, a to nejenom u forenzní populace, použít ke zjištování reakcí na frustraci více diagnostických metod, se kterými by se daly výsledky zkombinovat.

Znalost reakcí vězňů ve chvílích, kdy se vyskytnou ve frustrující situaci, by mohla př́ípadně usnadnit práci v rámci výchovných či resocializačních programů. Je-li známo, jakým způsobem se jedinec pravděpodobně zachová ve chvíli, kdy se necítí př́iliš komfortně, mohou být výchovné či resocializační programy nastaveny a zaměřeny tak, aby došlo jejich působením ke změně takového chování. I přes limity práce mohou mít uvedené výsledky svůj význam. Běžně se očekává, že forenzní populace bude více než populace běžná ke svému okolí agresivní. Jak výsledky této práce, tak výsledky výše popsaných studií ukazují, že ne vždy tomu tak musí skutečně být, a proto nelze očekávat výsledky na základě naučných stereotypů či očekávání. Pro další testování by bylo užitečné zkoumat větši skupinu jak odsouzených, kteř́ jsou již ve výkonu trestu, tak obviněných, u kterých teprve probíhá trestní rízení. Vhodné by bylo propojit zkoumanou skupinu nejenom se spáchaným deliktem, ale také např́klad s určitými osobnostními charakteristikami.

\section{Závěr}

Klíčovou problematikou práce byly termíny frustrace a reaktivita v souvislosti s pachateli trestné činnosti, kteř́ byli v době sběru dat ve výkonu trestu odnětí svobody. Hlavním cílem realizovaného výzkumu bylo zmapování způsobu reakcí u pachatelů trestné činnosti ve chvíli, kdy jsou podrobeni určité frustrující a zátěžové situaci. S ohledem na užití Rosenzweigova obrázkově frustračního testu obsahovaly frustrující situace dva hlavní typy - ego-blocking a super-ego blocking. Ego-blocking situace stavěly před jedince překážku, která jim znemožňovala uspokojit či dosáhnout žádoucího výsledku. Oproti tomu superego-blocking situace obsahovaly př́mý útok a obviňování zkoumané osoby.

V teoretickém úvodu práce byly popsány možné pohledy na reaktivitu a její podoby a projevy v kontextu zátěžových situací. Prostor byl věnován také frustraci, na kterou bylo nahlíženo nejprve pohledem klasických teoretiků a jejich vnímání pojmu a definice frustrace. Dále byly v teoretickém úvodu popsány rovněž možnosti zkoumání frustrace.

Realizované šetření na konkrétním výzkumném vzorku ukázalo, že nejvíce se u pachatelů trestné činnosti objevují reakce extragresivní oproti reakcím introagresivním a imagresivním. V porovnání s obecnou populací pachatelé trestné činnosti ovšem nevykazují vyšší míru extragresivních reakcí. $Z$ hlediska rozlišení trestných činů na činy s použitím násilí a bez použití násilí nebylo prokázáno, že by pachatelé násilné trestné činnosti více než pachatelé trestné činnosti bez použití násilí zdůrazňovali převládání frustrující př̌ekážky (obstacle-dominance) či častěji volili extrapeditivní ( $\left.E^{\prime}\right)$ zdůrazňování tíživosti situace.

Tematika reaktivity není $\mathrm{v}$ českém prostředí př́liš prozkoumané a propracované téma. Práce by tedy mohla být př́nosem pro další zkoumání a párování i s ostatními metodami, které by umožňovaly detailnější propojení frustrace a reaktivity u pachatelů trestné činnosti. 


\section{LITERATURA}

Agnew, R. (1985). A Revised Strain Theory of Delinquency. Social Forces, 64(1), 151-167.

Amsel, A., \& Roussel, J. (1952). Motivational properties of frustration: I. Effect on a running response of the addition of frustration to the motivational complex. Journal Of Experimental Psychology, 43(5), 363-368.

Archer, J. (2007). Physical aggression as a function of perceived fighting ability among male and female prisoners. Aggressive Behavior, 33(6), 563-573.

Berkowitz, L. (1962). Aggression: a social psychological analysis. New York: McGraw-Hill.

Blatníková, Š. \& Netík, K. (2008). Predikce vývoje pachatele. Praha: Institut pro kriminologii a sociální prevenci.

Braungart-Ricker, J. M., \& Stifter, C. A. (1996). Infants' responses to frustrating situations: Continuity and change in reactivity and regulation. Child Development, 67(4), 1767-1779.

Dennis, T. (2006). Emotional self-regulation in preschoolers: The interplay of child approach reactivity, parenting, and control capacities. Developmental Psychology, 42(1), 84-97.

Doob, L. W., \& Sears, R. R. (1939). Factors determining substitute behavior and the overt expression of aggression. The Journal Of Abnormal And Social Psychology, 34(3), 293-313.

Douglas, J. E., Ressler, R. K., Burgess, A. W., \& Hartman, C. R. (1986). Criminal Profiling from Crime Scene Analysis. Behavioral Sciences \& The Law, 4(4), 401-421.

Eisenberg, N., \& Miller, P. A. (1987). The relation of empathy to prosocial and related behaviors. Psychological Bulletin, 101(1), 91-119.

Giannell, A. S. (1966). Psychological Characteristic of Four Criminal-Offender Groups. Journal Of Social Psychology, 69(1), 55-72.

Gillernová, I., \& Boukalová, H. (2006). Vybrané kapitoly z kriminalistické psychologie. Praha: Karolinum.

Hornsveld, R. J., Nijman, H. I., Hollin, C. R., \& Kraaimaat, F. W. (2007). An adapted version of the Rosenzweig Picture-Frustration Study (PFS-AV) for the measurement of hostility in violent forensic psychiatric patients. Criminal Behaviour \& Mental Health, 17(1), 45-56.

Huck, J. L., Lee, D. R., Bowen, K. N., Spraitz, J. D., \& Bowers, J. H. (2012). Specifying the Dynamic Relationships of General Strain, Coping, and Young Adult Crime. Western Criminology Review, 13(2), 25-45.

Ireland, J. L. (2011). The importance of coping, threat appraisal, and beliefs in understanding and responding to fear of victimization: Applications to a male prisoner sample. Law And Human Behavior, 35(4), 306-315.

Jones, S. E., Miller, J. D. \& Lynam D. R. (2011). Personality, Antisocial Behavior, and Aggression: A Meta-Analytic Review. Journal of Criminal Justice, 39(4), 329-337.

Křivohlavý, J. (1994). Jak zvládat stres. Praha: Avicenum.

Lauterbach, O., \& Hosser, D. (2007). Assessing empathy in prisoners - A shortened version of the Interpersonal Reactivity Index. Swiss Journal Of Psychology / Schweizerische Zeitschrift Für Psychologie / Revue Suisse De Psychologie, 66(2), 91-101.

Lawson, R., \& Marx, M. H. (1958). A comparison of some presumed frustrating and secondary-reinforcing operations. Journal Of Comparative And Physiological Psychology, 51(6), 742-746.

Maier, N. (1966). Frustration: the study of behavior without a goal. Michigan: Arbor.

McMurran, M., \& Christopher, G. (2009). Social problem solving, anxiety, and depression in adult male prisoners. Legal \& Criminological Psychology, 14(1), 101-107.

Mohino, S., Kirchner, T., \& Forns, M. (2004). Coping Strategies in Young Male Prisoners. Journal Of Youth \& Adolescence, 33(1), 41-49.

MV ČR. (2015). Statistické přehledy. [online]. [Vyhledáno 11. 6. 2015 na http://www.policie.cz/clanek/policie-cr-web-informacni-servis-statistiky-statisticke-prehledy.aspx ].

Netík, K., Netíková, D., \& Hájek, S. (1997). Psychologie v právu: úvod do forenzní psychologie. Praha: C. H. Beck.

Okrouhlická, K. (2015). Reaktivita a tolerance $k$ frustraci z pohledu psychologie u odsouzených pachatelì trestné činnosti (Diplomová práce). Praha: FF UK.

Pedersen, W. C., Gonzales, C., \& Miller, N. (2000). The moderating effect of trivial triggering provocation on displaced aggression. Journal Of Personality And Social Psychology, 78(5), 913-927.

Rosenzweig, S. (1938). A General Outline of Frustration. Character \& Personality, 7(2), 151-160.

Rosenzweig, S. (1945). The Picture-Association Method and its Application in a Study of Reactions to Frustration. Journal Of Personality, 14(1), 3. 
Rosenzweig, S. (1976). Aggressive Behavior and the Rosenzweig Picture-Frustration (P-F) Study. Journal Of Clinical Psychology, 32(4), 885-891.

Shuman, D. W., \& Gold, L. H. (2008). Without Thinking: Impulsive Aggression and Criminal Responsibility. Behavioral Sciences \& The Law, 26(6), 723-734.

Schlesinger, L. B. (2004). Classification of antisocial behavior for prognostic purposes: study the motivation, not the crime. Journal Of Psychiatry \& Law, 32(2), 191-219.

Šípek, J. (2000). Projektivní metody. Praha: ISV.

Trestní zákoník, § 13 zákona č. 40/2009 Sb. [online]. [Vyhledáno 8. 5. 2015 na https://portal.gov.cz/app/zakony/ zakon.jsp?page $=0 \& n r=40 \sim 2 \mathrm{~F} 2009 \& \mathrm{rpp}=15 \#$ seznam $]$.

Vane, J. R. (1954). Implications of the Performance of Delinquent girls on the Rosenzweig Picture-Frustration Study. Journal Of Consulting Psychology, 18(6), 414.

Vasquez, E. A., Bartsch, V. O., Pedersen, W. C., \& Miller, N. (2007). The impact of aggressive priming, rumination, and frustration on prison sentencing. Aggressive Behavior, 33(6), 477-485.

Zuckerman, M., Kuhlman, D. M., Joireman, J., Teta, P., \& Kraft, M. (1993). A comparison of three structural models for personality: The Big Three, the Big Five, and the Alternative Five. Journal Of Personality And Social Psychology, 65(4), 757-768.

\section{REACTIVITY AND FRUSTRATION TOLERANCE FROM THE POINT OF VIEW OF PSYCHOLOGY IN SENTENCED PERPETRATORS OF CRIME}

\section{K. OKROUHLICKÁ}

\section{ABSTRACT}

The main topic of the article is reactivity, the way, how a person behaves in a situations under pressure or when achieving certain goal is blocked by an obstacle. The focus of the study is on sentenced criminal perpetrators. In Czech Republic the topic of reactivity is not well covered by the research, however knowing the types of reactions of sentenced persons in situation of frustration could be helpful in their resocialization.

The goal of the research was to gain quantitative data about the most frequented reactions in sentenced criminal perpetrators in the situations of facing an obstacle, that blocks achieving certain goal or need satisfaction. To find out the reactivity on frustration the Rosenzweig picture frustration method has been used. Only one of four hypothesis has been accepted - that the criminal perpetrators use most frequently extraggressive reaction, compared to intraaggressive and imaggressive reactions. The article and results come from the diploma thesis of the author (Okrouhlická, 2015).

Key words: reactivity, frustration, perpetrator, crime, pressure.

O autorce: Mgr. Kateřina Okrouhlická, policejní psycholog Krajského ředitelství policie hlavniho města Prahy.E-mail:katerina.okrouhlicka@gmail.com 